ACTA UNIVERSITATIS LODZIENSIS

FOLIA OECONOMICA 5(325) 2016

http://dx.doi.org/10.18778/0208-6018.325.07

Katarzyna Cheba*

\title{
THE APPLICATIONS OF VECTOR CALCULUS TO THE STUDY OF THE TEMPORAL UNIFORMITY OF DEVELOPMENT OF SOCIO-ECONOMIC OBJECTS
}

\begin{abstract}
Dynamic changes observed on global markets mainly due to the economic slowdown but also as in the case of Japan the effect of natural disasters, are the main reason for the need to take into account the new operating conditions in global logistics strategies of corporations. They also have a direct impact on decisions concerning the location of foreign investment. One of the factors increasingly influencing the location decisions of investors is the stability of economic development measured not only in relation to that country, but also the entire geographic region. This is particularly important in the case of such political and economic structures like the European Union, bringing together countries with significant differences in levels of development and with different conditions and experiences of functioning. The aim of this study is to analyze the temporal uniformity of indicators which could determine the attractiveness (economic competitiveness), of the European Union as a place for the location of foreign investment. For the study of this temporal uniformity the calculus vector was used. The results confirmed the considerable temporal diversity of development of the analyzed indicators. Presented results are part of a research project called "Management methods in Japanese supply chains in Poland and the UK", funded by the National Science Centre.
\end{abstract}

Keywords: vector calculus, temporal uniformity, regional analysis.

JEL: C38, O11, P36.

\section{INTRODUCTION}

The decisions concerning the location of the companies' activity are one of the first and the most important decisions made by foreign companies locating their capital in a given country. The selection of a particular country or region, which is supposed to become a location of a foreign investment, is influenced by many factors. The relevant literature (Hymer 1976, Frey, Schneider 1985: 161175, Blomstrom, Wang 1992: 137-155, Dunning 2003: 43-58, Pilarska 2005, Kojima 2011, Albulescu, Tămăşilă 2014: 219-228, Coy, Corrnicon 2014: 8-17,) mentions the economic conditions, including market determinants, cost determinants and the openness of economy, among the main factors affecting the value of direct investments in a given country. An elaborated list of factors

\footnotetext{
*West Pomeranian University of Technology Szczecin, Katarzyna.Cheba@zut.edu.pl
} 
deciding on the inflow of FDI was presented by Dunning (2004: 64-85, 2006: 23-38). In his opinion, the investors, when making a decision, take into account not only economic factors (dependent on the type of FDI) but also the political framework and business surroundings.

The list of determinants deciding on the attractiveness of a given area may include: market size and its growth, openness, distance and infrastructure (physical and cultural), corporate tax rates, labor market flexibility, quality of institutions, incentives used in the context of industrial and regional policy, exchange rates, agglomeration in a sense of regional concentrations of chosen industries and political stabilityandthe stabilityof the economyunderstood also as temporal uniformity of development. The last of the identified factors is especially important in a situation of dynamic changes in the business environment in modern economies and the lack of stability of the socio-economic development not only of individual countries but even whole geographical regions.

An interesting area of research in this field is the impact analysis of the macroeconomic situation on strategic decisions and logistic activities of companies locating their capital in European countries. This is particularly important for investors presenting a completely different level of socio-economic development and operating in other economic reality than in the case of European countries. An examination of the temporal uniformity of factors affecting the attractiveness of the region as a destination for foreign investment location is also important in the case of such socio-economic structures as the European Union which brings together countries with significant cultural differences in the level of socio-economic development.

The aim of the article is to analyze the temporal uniformity of socioeconomic development of European countries. The temporal uniformity of development can be seen by foreign partners investing their capital in this region as an important factor in the perception of a country's economy as competitive and thereby influencing location decisions. The study of temporal uniformity of socio-economic development of European countries, data from the report: The Global Competitiveness Index of the World Economic Forum was used. Analyses were conducted using vector calculus.

The article is divided into two main parts. The first one presents basic information about the research of competitiveness of the world's economies carried out annually by the World Economic Forum (WEF) and presented in the report: The Global Competitiveness Index (GCI), published since 2004. The second part of the study characterizes the use of vector calculus in order to explore the study of temporal uniformity of European economies. The discussion presented in the paper is a part of a research project entitled „Management methods in Japanese supply chains in Poland and Great Britain", financed by the National Science Centre. 


\section{COMPETITIVENESS OF ECONOMY - AS AFACTOR OF INVESTMENT ATTRACTIVENESS}

The development of a modern economy depends on its competitiveness, which is created by reducing barriers to business, development of education and activity in the internal market. The competitiveness is a multifaceted phenomenon which is both difficult to define and measure. This phenomenon in the economic literature (Porter 1985, Copeland 1997, Cheba 2015) can be studied both in the functioning and development of enterprises and entire industries, regions, countries, or even transnational groups. According to the definition of the OECD (Organisation for Economic Cooperation and Development) competitiveness is "the ability of companies, industries, regions, countries and supranational groupings to face international competition and to ensure a high rate of returns on the used factors of production, as well as the relatively high level of employment". It should be noted that the sum of competitiveness of enterprises operating in the economy does not mean (direct) assess of the competitiveness of the national economy, making the measurement of competitiveness extremely difficult. Because of the special role of business investment in socio-economic development, job creation or technological polarization of regions it is advisable to examine the attractiveness of the economic space (primarily understood as an attractive location for new investments) through the prism of its competitiveness.

One way to measure the level of competitiveness are the results of tests carried out annually by the World Economic Forum (WEF) and presented in the report: The Global Competitiveness Index (GCI), published since 2004. According this report: "competitiveness is defined as the set of institutions, policies and factors that determine the level of productivity of a country". The level of productivity, in turn, sets the level of prosperity that can be earned by an economy. The study involved about 150 countries and over ten thousand companies from all over world. In Poland, the WEF partner is the Polish National Bank. GCI score is calculated based on data covering 12 categories gathered in the so-called pillars of competitiveness, which together form a complete picture of the competitiveness of the country, these are: 1) Institutions, 2) Infrastructure 3) Macroeconomic environment, 4) Health and primary education, 5) Higher Education and Training, 6) Goods market efficiency, 7) Labor market efficiency, 8) Financial market development, 9) Technological readiness, 10) Market size 11) Business sophistication and 12) Innovation. The Global Competitiveness Index provides important information to potential investors about the level of competitiveness of an economy. It is very often the first step of selecting the markets in which to invest. In addition to the space occupied by an economy in this ranking it is also 
important to the stability of socio-economic development of the economy over time. Table 1 shows the development of the WCI index for the fastest growing economies in the world and Poland in the years 2005-2014.

Table 1. Rank in The Global Competitiveness Index for the fastest growing economies in the world and Poland in the years 2006-2014

\begin{tabular}{|l|r|r|r|r|r|r|r|r|c|}
\hline \multirow{2}{*}{ Country } & \multicolumn{9}{|c|}{ Rank } \\
\cline { 2 - 11 } & 2006 & 2007 & 2008 & 2009 & 2010 & 2011 & 2012 & 2013 & 2014 \\
\hline Switzerland & 4 & 2 & 2 & 1 & 1 & 1 & 1 & 1 & 1 \\
\hline Singapore & 8 & 7 & 5 & 3 & 3 & 2 & 2 & 2 & 2 \\
\hline USA & 1 & 1 & 1 & 2 & 4 & 5 & 7 & 5 & 3 \\
\hline Finland & 6 & 6 & 6 & 6 & 7 & 4 & 3 & 3 & 4 \\
\hline Deutschland & 7 & 5 & 7 & 7 & 5 & 6 & 6 & 4 & 5 \\
\hline Japan & 5 & 8 & 9 & 8 & 6 & 9 & 10 & 9 & 6 \\
\hline Honkong & 10 & 12 & 11 & 11 & 11 & 11 & 9 & 7 & 7 \\
\hline Netherlands & 11 & 10 & 8 & 10 & 8 & 7 & 5 & 8 & 8 \\
\hline United Kingdom & 2 & 9 & 12 & 13 & 12 & 10 & 8 & 10 & 9 \\
\hline Sweden & 9 & 4 & 4 & 4 & 2 & 3 & 4 & 6 & 10 \\
\hline Canada & 12 & 13 & 10 & 9 & 10 & 12 & 14 & 14 & 15 \\
\hline Denmark & 3 & 3 & 3 & 5 & 9 & 8 & 12 & 15 & 13 \\
\hline Poland & 45 & 51 & 53 & 46 & 39 & 41 & 41 & 42 & 43 \\
\hline
\end{tabular}

Source: own elaboration based on WEF data.

In the results provided in this table we can observe some basic regularities concerning qualified countries in a recent study to the top ten fastest growing economies in the world. Since 2012 generally there has not been a major change in the group of the ten fastest growing economies in the world. The leader of the group since 2009 remains Switzerland, a similar situation applies to Singapore, which since 2011 is invariably classified in the same second position. In the third place, for the first time since 2010, the US has been classified. Until 2009, the US occupied the first position in the analyzed ranking. The decline of the position of this country was due to the economic crisis. Improving the position occupied in the ranking also applies to Japan, which in 2014 was the sixth (in 2013 it was 9th). On the other hand, a systematic decline of position taken by Sweden (starting in 2011) has been observed. The position of Poland in the ranking presented is not the best and additionally since 2011 onwards declining steadily. In the last year Poland was ranked at 43rd place. Poland achieved the highest score in 2009 and it was at $39^{\text {th }}$ place. 
Investors analyzing the socio-economic and political situation of target investments in addition to various kinds of factors, including those presented in the form of increasingly popular rankings also take into account the stability of the development of the economy, which is evaluated by respondents participating in the survey. The temporal uniformity of indicators describing various areas of socio-economic development of the country or region is the most amazing factor taken into account while making a decision about the placement of capital in the event of turbulent changes in markets which is the best example of the economic crisis of 2008-2009.These observations were used in the rest of the paper to the study of temporal uniformity of development of the economies of the European countries participating in the WEF study based on vector calculus. The examination of the temporal uniformity of the factors determining the competitiveness of the EU economies on the basis of the vector calculus provides additional information that may be useful for extended studies concerning the location decisions of companies.

\section{METHODOLOGY OF THE RESEARCH OF THE TEMPORAL UNIFORMITY}

The paper presents a proposal for the use described in the literature (Nermend 2008, Nermend, Tarczyńska-Łuniewska 2013: 85-100) vector calculus to study the uniformity of development of the European countries. The vector calculus is very flexible and might be applied in economics, particularly in the case of vector measurement based on the scalar product and the arithmetic increments. The vector calculus, depending on the adopted manner of computation of incremental standard deviation and/or the increment of variance might be implemented to research: a) spatial uniformity of a set of elements located on a bigger spatial unit, for example the homogeneity of member states of European Union located over a bigger region and $b$ ) temporal uniformity of identified changes, for instance over the years. The paper discusses the second of the presented cases.

Calculations using vector measurement start with the designation of so-called ordered twos, which are used for further calculations instead of actual values. These twos form: the average and the standard deviation and the average and the variance. In the case of testing the temporal uniformity it is taken into account the values of the analyzed indicators in different periods of time (e.g. years) and it computes the average value $\left(\eta_{i}\right)$, standard deviation $\left(\sigma_{i}\right)$ and the variance $\left(\sigma_{i}{ }^{2}\right)$.

The next step is to determine increases based on which further calculations are conducted. Similar calculations are performed also for a pair: the average value and the variance. 


$$
\left(\begin{array}{cc}
\Delta \eta_{i, \Delta} \Delta \sigma_{i,} \\
j & j
\end{array}\right)=\left(\begin{array}{c}
\eta_{i}-\eta_{o}, \sigma_{i,}-\sigma_{o} \\
j
\end{array}\right)
$$

where: $\eta_{i}$ is the average $i$-this variable $j$-this object, $\Delta \sigma_{i}$, is standard deviation of $i$-this variable $j$-this object, $\eta_{o}, \sigma_{o}$ are reference points, respectively for the growth of the average and the standard deviation. Reference points can be chosen arbitrarily. In practice, in order to simplify a calculation most frequently it is taken as it equals zero.

Whereas the normalization of designated pair value should be based on the following formulas:

$$
\left(\begin{array}{c}
\Delta \eta_{i}^{\prime}, \Delta \sigma_{i}^{\prime} \\
j \\
j
\end{array}\right)=\left(\begin{array}{c}
\Delta \eta_{i}-\Delta \bar{\eta}_{i} \\
\frac{\Delta \sigma_{i}}{\sigma_{\eta_{i}}}, \frac{j}{\sigma_{\eta_{i}}}
\end{array}\right)
$$

and:

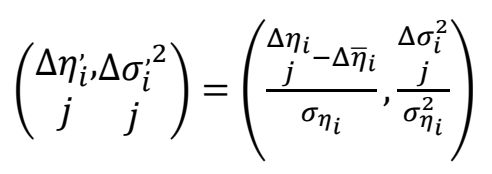

where: $\Delta \bar{\eta}_{i}$ - is an average value of average values, $\sigma_{\eta_{i}}$ i $\sigma_{\eta_{i}}^{2}$ is their standard deviation and variance.

Prior to the delimitation of synthetic measure a pattern is determined $\left(\Delta \eta_{i}^{\prime}\right)$ and

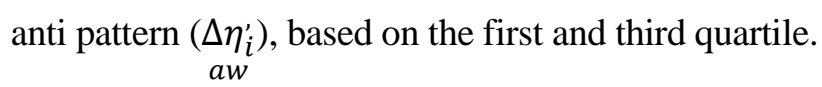

$$
\underset{w}{\Delta \eta_{i}^{\prime}}=\left\{\begin{array}{c}
\Delta \eta_{i}^{\prime} \\
k_{I I I} \\
\Delta \eta_{i}^{\prime} \\
k_{I}
\end{array}\right. \text { for destimulants }
$$

where: $\frac{\Delta \eta_{i}^{\prime}}{w}$ is the value of the $i$-th normalized variable for the pattern, $\frac{\Delta \eta_{i}^{\prime}}{k_{I}}$ is the value of the $i$-th normalized variable for the first quartile, $\frac{\Delta \eta_{i}^{\prime}}{k_{I I I}}$ is the value of the $i$-th normalized variable for the third quartile.

If the pattern is determined and based on quartiles it represents an unreal, idealized object. There is therefore no need to determine the deviation increases for its coordinates. They can be taken as zero.

Determination of aggregate measure based on the scalar ratio of vectors representing the objects and vectors pattern and anti-pattern is determined on the basis of the formula: 


$$
\Delta \mathrm{m}_{s \eta_{j}}=\frac{\sum_{i=1}^{M}\left(\Delta \eta_{i_{j}}^{\prime}-\Delta \eta_{i}^{\prime}\right)\left(\Delta \eta_{i_{w}}^{\prime}-\Delta \eta_{i w}^{\prime}\right)}{\sum_{i=1}^{M}\left(\Delta \eta_{i_{w}}^{\prime}-\Delta \eta_{i w}^{\prime}\right)^{2}}
$$

To determine the vector of synthetic measure the throw rate is used. Therefore, the factor can't be determined for the standard deviation and variance, it is assumed that the measurement is designated around the point of the position of the object in space by hyperball.This allows you to determine the maximum possible deviation of synthetic measure $\mathrm{w}$ based on the standard deviation of ratio line, according to the (NermendiTarczyńska-Łuniewska 2013):

$$
j_{s \sigma \max }=\frac{\max _{i}\left(\Delta \sigma_{i}^{\prime}\right)}{\sqrt{\sum_{i=1}^{M}\left(\Delta \eta_{i_{w}}^{\prime}-\Delta \eta_{i}^{\prime}\right)^{2}}}
$$

and the variance of ratio line (Nermend and Tarczyńska-Łuniewska 2013):

$$
\Delta m_{s \sigma^{2} \max }=\frac{\sqrt{\max _{i}\left(\Delta \sigma_{i}^{\prime 2}\right)}}{\sqrt{\sum_{i=1}^{M}\left(\Delta \eta_{i_{w}}^{\prime}-\Delta \eta_{i}^{\prime}\right)^{2}}}
$$

In order to determine the maximum possible deviation of synthetic measure designated in this way a greater value is selected.

The next step is to assign the tested objects (European countries) to the appropriate classes. On the basis of increments of standard deviations and increments of the variance the maximum value of the standard deviation can be determined, which can be interpreted as a measure of the uniformity of development. The lower the value of this measure the greater uniformity, and the smaller the differences between the objects.

\section{RESULTS AND DISCUSSION}

The study was conducted on a sample of 37 European countries identified on the basis of database of the WEF. The proposed index is a composite, which means that it is calculated as a weighted average of partial measures. The main data set contained a total of 114 diagnostic features that describe the three considered areas of competitiveness: 
a) basic requirements subindex (key for factor-driven economies), which includes area of: institutions, infrastructure, macroeconomic environment and health and primary education. Its weight is the biggest in economies in the first stage of development, so as it is in the case of economies based mainly on the resources of the factors of production.

b) efficiency enhancers sub-index (key for efficiency-driven economies), which includes area of: higher educations and training, goods market efficiency, labor market efficiency, financial market development, technological readiness and market size. Its importance increases with the transition to the second stage in the development of competitiveness to strive to improve production efficiency and its quality.

c) innovations and business sophistications factors subindex (key for innovation-driven economies), which includes area (pillar) of: business sophistication and innovation. It is most important for countries whose development is based mainly on its capacity for innovation.

In the study the third considered area was analyzed. This area was chosen as the most important when considering the location decision by most innovative large companies. This area contained 16 diagnostic features: a) in the pillar of business sophistication 9 diagnostic features - local supplier quantity $\left(x_{1}\right)$, local supplier quality $\left(x_{2}\right)$, state of cluster development $\left(x_{3}\right)$, nature of competitive advantage, production process sophistication $\left(x_{4}\right)$, willingness to delegate $\left(x_{5}\right)$, authority $\left(x_{6}\right)$, control of international distribution $\left(x_{7}\right)$, extent of marketing $\left(x_{8}\right)$, value chain breadth $\left.\left(x_{9}\right), \mathrm{b}\right)$ in the pillar of innovation 7 diagnostic features - capacity for innovation $\left(x_{10}\right)$, quality of scientific research institutions $\left(x_{11}\right)$, company spending on $\mathbf{R} \& \mathbf{D}\left(x_{12}\right)$, university-industry collaboration in $\mathrm{R} \& \mathrm{D}\left(x_{13}\right)$, Gov't procurement of advanced tech products $\left(x_{14}\right)$, availability of scientists and engineers $\left(x_{15}\right)$, PCT patents, applications/ million population $\left(x_{16}\right)$.

To study the temporal uniformity of development of the European economies in the area of innovations and business sophistications the data was used from 2008-2014. Table 2 shows the descriptive characteristics of selected indicators of the most diverse identified 2 areas of innovations and business sophistications factors sub-index presented in a geographical regions of Europe:

a) Western Europe (Austria, Belgium, France, Germany, Luxembourg, Netherlands, Switzerland),

b) Northern Europe (Denmark, Estonia, Finland, Iceland, Ireland, Latvia, Lithuania, Norway, United Kingdom, Sweden),

c) Southern Europe (Albania, Croatia, Slovenia, Spain, Portugal, Macedonia FYR, Malta, Greece, Italy, Cyprus),

d) Eastern Europe (Czech Republic, Hungary, Bulgaria, Poland, Romania, Slovak Republic, Ukraine).

From the study were excluded: Bosnia and Herzegovina, Moldova, Montenegro, Serbia, due to lack of data throughout the entire period. 
The applications of vector calculus to the study of the temporal uniformity...

Table 2. Descriptive statistics of two pillars of innovations and business sophistications factors subindex (average value of 2006-2014)

\begin{tabular}{|l|l|c|c|c|c|}
\hline \multirow{2}{*}{ Pillars } & \multirow{2}{*}{ Descriptive statistics } & \multicolumn{4}{c|}{ Europe } \\
\cline { 3 - 6 } & & Western & Northern & Southern & Eastern \\
\hline \multirow{5}{*}{ Business sophistications } & Average & 5.46 & 4.89 & 4.23 & 3.87 \\
& Minimum & 4.96 & 3.93 & 3.51 & 3.58 \\
& Maximum & 5.79 & 5.64 & 4.83 & 4.13 \\
& Range & 0.83 & 1.71 & 1.32 & 0.55 \\
& Coefficient of Variation (\%) & 5.15 & 11.63 & 9.08 & 5.57 \\
\hline \multirow{5}{*}{ Innovations } & Average & 4.94 & 4.43 & 3.42 & 3.19 \\
& Minimum & 4.46 & 3.11 & 2.95 & 2.94 \\
& Maximum & 5.66 & 5.65 & 3.80 & 3.56 \\
& Range & 1.20 & 2.54 & 0.85 & 0.62 \\
& Coefficient of Variation (\%) & 7.83 & 18.28 & 7.78 & 6.08 \\
\hline
\end{tabular}

Source: own elaboration based on WEF data.

Differences in average values between the analyzed regions of Europe are considerable. The lowest values of synthetic sub-indices were obtained in the case of Eastern Europe, while the highest values concern the countries located in Western Europe. The largest difference between the average maximum and minimum values apply to Northern Europe, which also had the highest evaluation of the coefficients of variation. The next stage of the analysis was to evaluate the temporal uniformity of factors describing the area of innovations and business sophistication using vector calculus. The analyzed indicators were standardized and on their basis the synthesis measurements were determined and objects were divided into classes. The calculations started with the appointment of averages, standard deviations and variances of the data for individual countries obtained in following years. Increments are calculated by subtracting from individual zero. The results of uniformity of development during the analyzed states are shown in Table 3 and Figure 1.

Table 2. The division of Europe into classes-summary

\begin{tabular}{|l|l|c|}
\hline \multirow{2}{*}{ Region } & \multicolumn{2}{|c|}{ The division of Europe into classes due to: } \\
\cline { 2 - 3 } & $\begin{array}{c}\text { the level of development } \\
\text { of an average country } \\
\text { in 2006-2014 }\end{array}$ & $\begin{array}{c}\text { temporal uniformity } \\
\text { (the ratio of the maximum increases in the } \\
\text { standard deviation to the width of the class) }\end{array}$ \\
\hline Western Europe & Cluster I & $50 \%$ and less \\
\hline Eastern Europe & Cluster II & $50-70 \%$ \\
\hline Southern Europe & Cluster III & $70-90 \%$ \\
\hline Northern Europe & Cluster IV & $90 \%$ and more \\
\hline
\end{tabular}

Source: own calculations. 


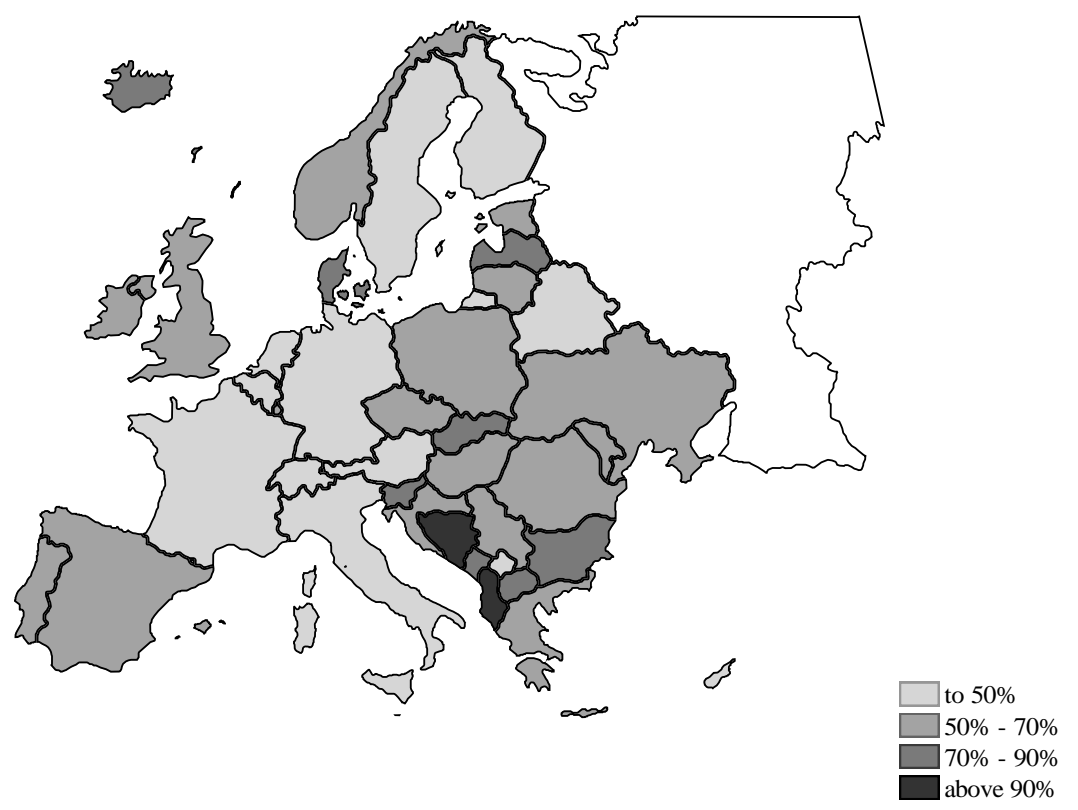

Figure 1. The division into classes due to the temporal uniformity of the development

Source: own calculation.

The values obtained during the study should be interpreted as follows: the average values and increases in average values represent the average values of the variables for the countries analyzed in the coming years, standard deviation, variance and their increments determine the variability in time variable, in this case the variability of individual countries. The results of presented rankings show that the greatest heterogeneity of development within time is characteristic for the countries of Southern and Northern Europe. This means that the countries located in this part of Europe are much more varied and can be classified into different classes. In the case of Southern Europe they are all considered classes. In contrast, a much smaller unevenness of development within time is characteristic for the countries of Western Europe and Eastern Europe.

\section{CONCLUSIONS}

The article presents the method for constructing synthetic vector measure which allows to determine the effect of indicators' variability on the result of ranking. The results of a study based on data describing the competitiveness of 
European economies show their high heterogeneity of development over time. The summary results of the categorization of countries, as well as the results of homogeneity testing development over time allow you to identify those countries where there are significant disparities in the development. A look at the structure of the development during the analyzed countries leads to a more comprehensive analysis of the development of not only individual countries but also the regions in which these countries are located. The results are a part of more comprehensive analyses, also including other areas of research of competitiveness of European economies, with particular emphasis on the uniformity of development in both time and space.

\section{REFERENCES}

Albulescu C.T., Tămăşilă M. (2014), The impact of FDI on entrepreneurship in the European Countries, "Procedia - Social and Behavioral Sciences", vol. 124, p. 219-228.

Blomstrom M., Wang J-Y. (1992), Foreign investment and technology transfer: A simple model, "European Economic Review", vol. 36/1, p. 137-155.

Cheba K. (2015), The perspectives of development of modern world industry - the comparative analysis of Poland and Japan industries, "Research Papers of Wrocław University of Economics", vol. 382, p. 29-40.

Copeland T., Koller T., Murrin J. (1997), Wycena: mierzenie i ksztattowanie wartości firm, WIG Press, Warszawa.

Coy R., Cormican K. (2014), Determinants of foreign direct investment: an analysis of Japanese investment in Ireland using the Kano model, "Investment Management and Financial Innovations", vol. 11, p. 8-17.

Dunning J.H. (2003), The Role of Foreign Direct Investment in Upgrading China's Competitiveness, "Journal of International Business and Economy", vol. 4, no. 1, p. 43-58.

Dunning J.H. (2006), Determinants of Foreign Direct Investment: Globalization-Induced Changes and the Role of Policies, World Bank: Washington, p. 64-85.

Dunning J.H. (2006), Towards a New Paradigm of Development: Implications for the Determinants of International Business, "Transnational Corporation”, vol. 15, no. 1, p. 23-38.

Frey B.S., Schneider F. (1985), Economic and political determinants of foreign investment, "World Development", vol. 13, no. 2, p. 161-175.

Hymer S. M. (1976), The international operations of national firms: A study of direct foreign investment, The MIT Press, Cambridge, Massachusetts and London, England.

Kojima K. (2011), Direct foreign investment. A Japanese Model of Multinational Business Operations, Routledge, Taylor and Francis Group, London and New York.

Nermend K. (2008), Rachunek wektorowy w analizie rozwoju regionalnego, Wydawnictwo Naukowe Uniwersytetu Szczecińskiego, Szczecin.

Nermend K., Tarczyńska-Łuniewska M. (2013), Badanie jednorodności przestrzennej i czasowej rozwoju obiektów społeczno-gospodarczych, „Przegląd Statystyczny” R. LX, z. 1, p. 85-100.

Pilarska Cz. (2005), Bezpośrednie inwestycje zagraniczne w teorii ekonomii, Wydawnictwo Akademii Ekonomicznej w Krakowie, Kraków.

Porter M. (1985), Competitive Advantage. Creating and Sustaining Superior Performance, The Free Press: New York. 


\section{Katarzyna Cheba}

\section{ZASTOSOWANIE RACHUNKU WEKTOROWEGO DO BADANIA JEDNORODNOŚCI CZASOWEJ ROZWOJU OBIEKTÓW SPOŁECZNO-GOSPODARCZYCH}

Streszczenie. Dynamiczne zmiany obserwowane na rynkach światowych związane przede wszystkim ze spowolnieniem gospodarczym, ale również będące, jak w przypadku Japonii efektem katastrof naturalnych, są głównym powodem konieczności uwzględniania nowych warunków funkcjonowania $w$ globalnych strategiach korporacji. Mają one również bezpośredni wpływ na decyzje dotyczące lokalizacji zagranicznych inwestycji. Jednym z czynników coraz bardziej wpływającym na decyzje lokalizacyjne inwestorów jest stabilność rozwoju gospodarki rozpatrywana nie tylko w odniesieniu do danego kraju, ale również całego regionu geograficznego. Jest to szczególnie istotne w przypadku takich konstrukcji politycznogospodarczych jak Unia Europejska, skupiających kraje o znacznych różnicach w poziomie rozwoju oraz o odmiennych warunkach i doświadczeniach funkcjonowania. Celem pracy jest analiza jednorodności zmian w czasie wskaźników mogących decydować o atrakcyjności (konkurencyjności gospodarki) Europy jako miejsca dla lokalizacji zagranicznych inwestycji. Do badania jednorodności rozwoju w czasie badanych obiektów społeczno-gospodarczych wykorzystany został rachunek wektorowy. Wyniki badań potwierdziły znaczną niejednorodność rozwoju w czasie analizowanych wskaźników. Przedstawione w pracy rozważania są częścią projektu badawczego pt. „Metody zarządzania w japońskich łańcuchach dostaw w Polsce i Wielkiej Brytanii”, finansowanego ze środków Narodowego Centrum Nauki.

Słowa kluczowe: rachunek wektorowy, jednorodność rozwoju w czasie, analizy regionalne.

JEL: C38, O11, P36. 